\title{
Prospects for the Development of Renewable Energy in the Crimean Peninsula*
}

V.V. Guryev, Post-graduate, Institute of Nuclear Energy and Industry of Sevastopol State University; "SO UES “Chernomorkoye RCD” JSC, Sevastopol, Russia

V.V. Kuvshinov, PhD in Engineering, Institute of Nuclear Energy and Industry of Sevastopol State University, Sevastopol, Russia

B.A. Yakimovich, DSc in Engineering, Professor, Institute of Nuclear Energy and Industry of Sevastopol State University, Sevastopol, Russia

The Crimean Peninsula is the flagship of the development of renewable energy, as it is not only an actively developing region, but also a resort center. The energy complex of the Crimean Peninsula in recent years has increased due to the construction of new power plants (Balaklava TPP and Tavricheskaya TPP) with a total capacity of 940 $M W$, as well as the construction of new 220 and $330 \mathrm{kV}$ transmission lines, which ensured that the peninsula's power supply deficit was covered. A review of the regional development and use of renewable energy sources is carried out. Based on the data obtained, an analysis is made of the problems and prospects for the development of renewable energy in the region.

The development of renewable energy for the Crimean Peninsula plays an important role in order to achieve environmental safety and develop the economic potential of the region. The paper substantiates the priority use of renewable energy in the region, as well as the solution of emerging problems with an increase in the share of renewable energy in the total generation. The appearance of excess electricity in the power system and the possibility of balancing the generated power of renewable energy and thermal power plants, while reducing the cost of electricity. Investment attractiveness and active population growth in the region leads to an increase in generating capacity and an increase in the maneuverability of the energy system with a significant impact of RES. The efficiency of renewable energy in the energy system, the world experience in managing renewable energy generation, the actual impact of renewable energy on the energy system in conditions of electricity shortage, and forecast work schedules of the SES wind farm provided by the electric power industry entities in the assigned way are taken into account when forming the dispatch schedule and are accepted at the request of the subject.

The available experience of existing SES in the power system of the Republic of Crimea and the city of Sevastopol requires additional research, including through field testing of generating equipment. Further full-scale tests should be carried out under the conditions of a real electric power mode of the power system, which requires the introduction of modern information technologies that ensure the exchange of technological information and the implementation of appropriate control actions. The work is underway to create a regulatory framework for the control of renewable energy source operation.

Keywords: power balance, ecology, renewable energy, solar and wind energy, field tests.

\section{Introduction}

I $\mathrm{n}$ the modern world with limited energy resources and increasing consumption, technologies for producing energy from alternative renewable sources are gaining more and more popularity. These sources include, first of all, solar and wind energy. In many developed countries that pay great attention to the development of renewable energy, programs have been adopted to develop and increase the volume of use of this type of energy and special regulatory legal acts that establish legal requirements and rules in this areas. Thus, the European Union decided to increase the share of non-traditional renewable energy sources in the energy balance to $20 \%$ by 2021 , and Sweden intends to achieve complete independence from fossil fuels during the same time. In countries where the share of renewable energy sources (RES) in the energy balance is the highest, for example, in Finland $(30 \%)$ and Denmark $(25 \%)$, state programs have been developed to support renewable energy. In the Russian Federation, in turn, the approved "Energy Strategy of Russia" for the period up to 2030, which provides for the introduction of alternative energy in all spheres of state activity and conditionally identifies three blocks of political and economic tasks, among which the increase in the relative volume of production is in the first place and electricity consumption using renewable energy sources from about 0.5 to $4,5 \%$ [1].

Do not forget that Russia has the world's largest potential for energy generated by alternative

\footnotetext{
(C) Guryev V.V., Kuvshinov V.V., Yakimovich B.A., 2019

${ }^{*}$ Статья на русском языке DOI: 10.22213/2413-1172-2019-4-116-123 (in Russ.).
} 
sources. Thus, the volume of technically available resources of renewable energy sources in the Russian Federation is at least 24 billion tons of standard fuel.

As for foreign experience, in this case, I would like to note Germany as a leading state in the development of renewable energy sources. In Germany, the proportion of weather-dependent electricity from wind and solar power continues to grow. This puts pressure on the electricity sector to be more flexible in managing energy demand and supply. The need for accurate forecasts of how much energy will be supplied to the grid at any moment is becoming increasingly acute. Accurate weather forecasts are essential, so network operators - electricity suppliers - and power plant operators rely on a new industry specializing in forecasting for the sector.

Even before the proliferation of renewables, grid operators used weather forecasts to make sure equipment was ready for extreme conditions and to complete maintenance work before a thunderstorm struck. The proliferation of renewable energy sources means that weather also matters for grid stability.

Network operators are responsible for balancing supply and demand in the German energy system. In the production of energy from fossil fuels, maintaining stability was a game with several variables, most of which could be controlled. With an everincreasing number of power supplies coming from non-permanent sources, maintaining balance is a laborious and costly endeavor that requires competence and awareness.

Sudden drops or surges in the power supply are a big problem for maintaining the stability of the network. Before and after the partial solar eclipse on March 20, 2015, German grid operators had to balance the 2,674 MW drop and the 4,111 MW surge in solar power within 15 minutes, when the power was changing four times faster than usual. With the growing share of renewable energy sources that are volatile, such leaps occur more often [2].

It is worth noting that the main advantage of alternative energy sources is inexhaustibility and environmental safety during the operation of these installations based on them, in connection with which it can be concluded that this direction has great development prospects.

The purpose of this study is to review the development and use of renewable energy sources under various regional aspects. Within the framework of this work, the potential for the development of re- newable energy in the Crimean Peninsula is considered.

\section{Potential and development prospects of renewable energy sources on the territory of the Crimean Peninsula}

The power complex of the Crimean Peninsula has increased in recent years due to the construction of new power plants (Balaklava TPP and Tavricheskaya TPP) with a total capacity of $940 \mathrm{MW}$, as well as the construction of new power lines with a capacity of 220 and $330 \mathrm{kV}$, which ensured coverage of the power supply deficit of the peninsula, increased its energy security. These results were achieved thanks to the federal target program [3].

Taking into account the development of global trends, one should not forget about the existing potential of the Crimean Peninsula in terms of renewable energy, where the share of the total generating capacity is about $30 \%$.

It is worth noting that with the parallel operation of renewable energy sources and thermal power plants, power is delivered (about $80 \mathrm{MW}$ ) through the energy bridge to the Kuban energy system. This fact indicates the presence of an excess of electricity in the energy system and the possibility of balancing the generated capacity of renewable energy sources and thermal power plants, while the cost of electricity decreases. Achievement of such a result became possible due to more accurate forecasting of electricity generation by renewable energy sources with short-term and operational planning of the energy regime of the power system operation.

Analysis of the potential of renewable energy sources on the Crimean Peninsula indicates the possibilities and expediency of their wider use in the field in order to save heat and fuel on existing traditional heat sources [4].

The implementation of the federal target program, as well as significant investment activity in the energy complex in relation to renewable energy sources, prompts the solution of more global problems in the operation of renewable energy sources in the region. In the future, the share of renewable energy sources in the energy system will increase, which means that the influence of variable renewable energy sources on the operating mode of the energy system will increase, which will require the development of more serious and accurate methods for managing the generation of renewable energy sources.

The economically feasible achievable potential for the development of renewable energy sources in Crimea is estimated at 620 thousand MW*h / year. 


\section{Renewable energy efficiency}

in the power system of the Republic of Crimea and the city of Sevastopol

The indicators of the efficiency of RES work are traditionally the coefficients of efficiency and the use of the installed capacity (ICUF) of power plants. The efficiency coefficient of RES (SPP and WPP), as a rule, does not exceed $30 \%$ and largely depends on climatic conditions, technical condition and technological perfection of equipment. KIUM characterizes the efficiency of the generating equipment and is equal to the ratio of the arithmetic mean power to the installed power of the electrical installation for a certain time interval [5].

Over the past three years, the CIUM of the renewable energy sources of the Crimean energy system does not exceed $15 \%$. For comparison: the indicators of RES work in China, which is the vanguard in the development of renewable energy technologies in the world, the CIUM WPP is $17.2 \%$, the CIUM SES - $15 \%$. In the countries of the European Union, the average ICUF indicator of WPP is slightly higher and amounts to $20.9 \%$, ICUF SES - $11.5 \%$.

It should be noted that, according to the studies of the International Energy Agency (IEA), there are four stages of introducing renewable energy generation into traditional energy systems [6].

At the first stage, when the share of renewable energy sources in the annual generation does not exceed 3\%, special measures for its integration are usually not required, unless renewable energy sources are highly localized in the energy system.

At the second stage, when the share of renewable energy sources is $3 \ldots 15 \%$, it is necessary to adapt the existing regulation resources, technologies and methods of managing the energy system.

At the third stage, when the share of renewable energy sources exceeds $15 \%$ of the annual output, as well as at further stages, a deep restructuring of the power system operation and the introduction of new means and tools to maintain the power system operation are required.

At the fourth stage - more than $50 \%$ of the annual output of RES generation - even greater flexibility of the system is required, its ability to selfrecover after sharp and volumetric fluctuations in output.

According to research, the average ICUF of renewable energy sources operating in the power system of the Republic of Crimea and the city of Sevastopol amounted to $15 \%$ over the past three years.

Thus, the generation of renewable energy sources can be attributed to the second stage of im- plementation in traditional energy systems, when the share of renewable energy sources is $3 \ldots 15 \%$, however, it is necessary to adapt the existing regulation resources, technologies and methods of controlling the energy system [7].

\section{The impact of renewable energy sources}

on the operational dispatch control

of the power system of the Republic of Crimea and the city of Sevastopol

From the point of view of operational dispatch control in the electric power industry, the assessment of the effectiveness of the participation of SPP and WPP in the coverage of consumption in the energy system is of particular interest. Despite the probabilistic nature and lack of guarantee of the generation of electric power by such power plants, in deficit energy systems, the operation of RES can have a systemic effect. A striking example is the operation of SPP and WPP in the Crimean power system during the blackout period with an acute shortage of active power in an isolated power system. So, when passing through the autumn-winter period 2016/17, the maximum load was recorded during the daytime and was provided, among other things, by the operation of renewable energy sources. In the evening hours, in conditions of a decrease in the generation of renewable energy sources and the exhaustion of the available capacity of generating sources, some consumers were transferred to power supply from decentralized sources, schedules of restrictions on the consumption regime were introduced [8].

In the conditions of the power system in the presence of reserves of active power of generating sources, the operation of RES is also in demand in a number of cases. For example, during the passage of the PEVT in 2018 in the Crimean power system, the maximum load was also recorded in the daytime. At the same time, the work of renewable energy sources allowed unloading the section of the IES of the South of Crimea below the level of the permissible flow (operation of the power bridge in a forced mode), as well as disconnecting part of the expensive mobile gas turbine power plants in reserve for the duration of solar activity. Thus, the optimization of the operating mode of the entire power system in manual mode took place.

It should be noted that the forecast schedules for the operation of SPP and WPP, provided by the subjects of the electric power industry in the prescribed manner, are taken into account when forming the dispatch schedule and are accepted at the request of the subject. In this sense, the quality of forecasting carried out at power plants seems to be important [9]. 
An important factor influencing the power system is the non-guaranteed generation of electric power by such power plants. The figure shows an example of the deviation of the predicted value from the actual one. This deviation of the RES operating mode in the Crimean power system was recorded on January 23, 2019.

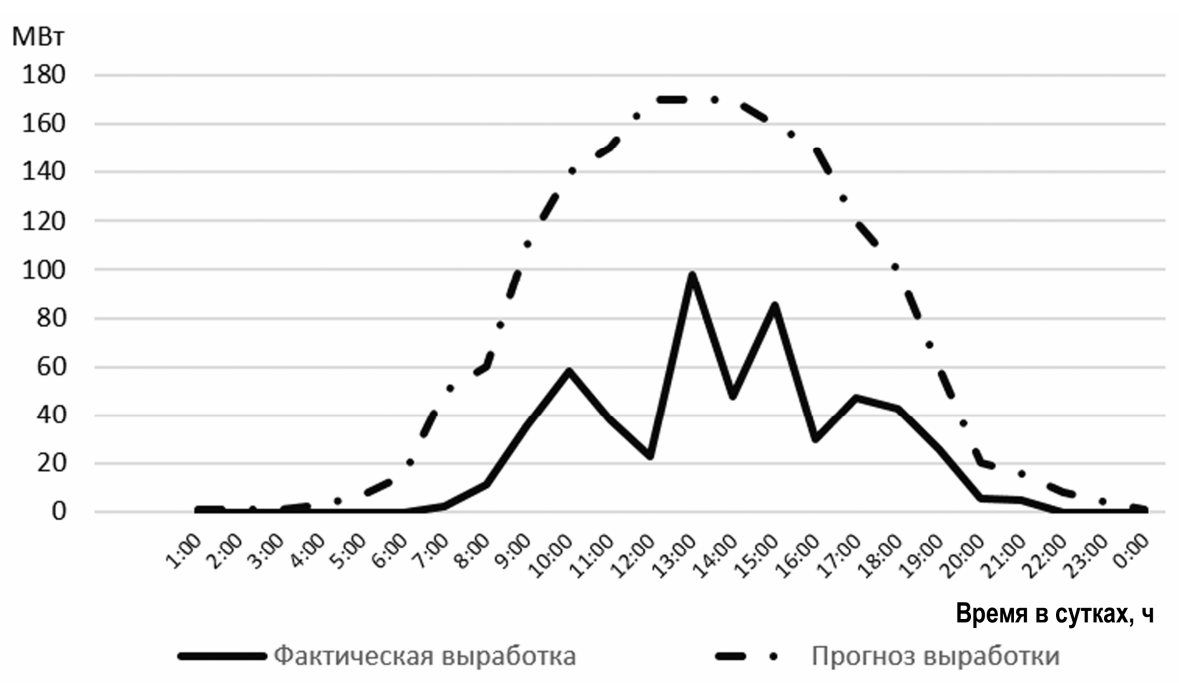

Deviation of the actual renewable energy sources generation from the forecast value

If we take into account that the time interval between the decision to turn on the generator into the network and the turn-on itself is determined by the duration of start-up operations and for thermal power plant facilities is measured in hours, then it is necessary to determine in advance which generating facilities and in which queues should be included in the work to pass the maximum load; to pass the periods of minimum load, it is also required to determine which objects can be disconnected from the network and transferred to the cold reserve [10]. The absence on the renewable energy market of universal technical devices and control means that provide the possibility of combining various types of power plants within a single energy system with the possibility of efficient control of their operation modes is a negative factor in the development of renewable energy not only in the Crimean energy system. We, but also the UES of Russia as a whole.

With a more accurate determination of the generated power of renewable energy sources, the optimal load of power plants operating on a traditional type of fuel is actually determined, which, in turn, allows more efficient use of the power of thermal power plants and saves fuel in the complex operating in a power system with renewable energy sources.

\section{Experience in managing renewable} energy sources in power systems

The existing experience of operating SPPs in the power system of the Republic of Crimea and the city of Sevastopol requires additional research, including through field tests of generating equipment.

Tests of remote control of the Buribaevskaya SPP operating mode from the dispatch center are of particular interest. Conducted by the branches of JSC "System Operator of the Unified Energy System" United Dispatch Control" (JSC "SO UES "ODU") of the Urals and the Bashkir Regional Dispatch Administration together with the group of companies "Hevel", as well as field tests of the function of limiting the active power of SolIletskaya SES in order to determine the possibility of the actual participation of SES in the HRO, held in the operating area of the branch of JSC "SO UES" of the Orenburg Regional Dispatch Office [11].

Carrying out such experiments is associated with the adjustment of the SES inverters, through which the power generated by a group of photoelectric modules (solar panels) is supplied to the electrical network. In this case, the value of the active power limitation with increasing frequency corresponds to the preset inverter settings for statism and the "dead band" of the primary regulation [12]. These tests are simulation and are implemented using the existing software and hardware systems.

Thus, further full-scale tests should be carried out in the conditions of a real electric power mode of operation of the power system, which requires the introduction of modern information technologies that ensure the exchange of technological in- 
formation and the implementation of the corresponding control actions.

\section{Building an optimal model}

for managing renewable energy sources

in the power system of Crimean Peninsula

In order to reduce the cost of generating and transmitting electricity, taking into account the increase in the reliability of the power system under the influence of RES, a mathematical optimization model has been built. As a result, the participants in the power system were divided into the following groups:

- CHP - thermal power plants;

- MGTPP - mobile gas turbine power plants;

- RES - renewable energy sources;

- RISE - backup power supply sources;

- power bridge (cable-overhead lines (hereinafter referred to as $\mathrm{KVL}$ ) of power transmission lines and substations built to connect the Crimean power system to the UES of Russia (IES of the South)).

\section{Calculation of various scenarios of energy supply of the Crimean Peninsula}

\begin{tabular}{|c|c|c|c|c|}
\hline $\begin{array}{l}\text { Scenario } \\
\text { number }\end{array}$ & $\begin{array}{c}\text { Consumption load, } \\
\text { MW }\end{array}$ & $\begin{array}{c}\text { Maximum power of sources, } \\
\text { MW }\end{array}$ & $\begin{array}{c}\text { Actual available } \\
\text { generation capacity, MW }\end{array}$ & $\begin{array}{c}\text { Power system } \\
\text { capacity deficit, MW }\end{array}$ \\
\hline 1 & 1591 & $\begin{array}{l}\text { CHP }-1254 \\
\text { MGTPP }-396,1 \\
\text { RES }-20 \\
\text { power bridge }-720\end{array}$ & $\begin{array}{l}\text { CHP }-800 \\
\text { MGTPP }-0 \\
\text { RES }-20 \\
\text { power bridge }-690\end{array}$ & -81 \\
\hline 2 & 1430 & $\begin{array}{l}\text { CHP }-1254 \\
\text { MGTPP }-396,1 \\
\text { RES }-230 \\
\text { power bridge }-720\end{array}$ & $\begin{array}{l}\text { CHP }-800 \\
\text { MGTPP }-0 \\
\text { RES }-230 \\
\text { power bridge }-650\end{array}$ & 250 \\
\hline 3 & 1630 & $\begin{array}{l}\text { CHP }-1254 \\
\text { MGTPP }-396,1 \\
\text { RES }-20 \\
\text { power bridge }-720\end{array}$ & $\begin{array}{l}\text { CHP }-800 \\
\text { MGTPP }-0 \\
\text { RES }-20 \\
\text { power bridge }-720\end{array}$ & -90 \\
\hline 4 & 1350 & $\begin{array}{l}\text { CHP }-1254 \\
\text { MGTPP }-396,1 \\
\text { RES }-230 \\
\text { power bridge }-720\end{array}$ & $\begin{array}{l}\text { CHP }-800 \\
\text { MGTPP }-0 \\
\text { RES }-230 \\
\text { power bridge }-350\end{array}$ & 130 \\
\hline 5 & 1200 & $\begin{array}{l}\text { CHP }-1254 \\
\text { MGTPP }-396,1 \\
\text { RES }-230 \\
\text { power bridge }-720\end{array}$ & $\begin{array}{l}\text { CHP }-850 \\
\text { MGTPP }-0 \\
\text { RES }-230 \\
\text { power bridge }-0\end{array}$ & 120 \\
\hline
\end{tabular}

The first scenario showed the dependence of the energy system and consumers on renewable energy sources. There was a disconnection of the load of consumers of about $81 \mathrm{MW}$. The reason for this situation was the lack of generating capacities, restrictions on the flow with the power bridge, and unfavorable meteorological factors.

The second scenario showed that under favorable meteorological conditions on a sunny day and, accordingly, in the presence of additional generation of renewable energy sources during the operational planning and maintenance of the power system mode, there was no disconnection of the consumers' load. At the same time, there is a capacity reserve of $250 \mathrm{MW}$ at the MGTPP.

The third scenario showed the dependence of the energy system and consumers on renewable energy sources. There was a disconnection of the load of consumers of about $90 \mathrm{MW}$. The reason for this situation was the lack of generating capacities, restrictions on the flow with the power bridge, and unfavorable meteorological factors.
The fourth scenario, under favorable meteorological conditions on a sunny day and repairs at the power bridge, showed that it is possible to abandon expensive MGTPPs even at peak electricity consumption.

The fifth scenario, under favorable meteorological conditions on a sunny day, showed that it is possible to abandon the expensive MGTPP. In this case, it is possible to supply electricity to the mainland through an energy bridge of about $120 \mathrm{MW}$ [13].

It should be noted that in the summer period, the generated capacity of renewable energy sources under unfavorable natural conditions can decrease by almost $90 \%$, while a significant part of the generating capacities of thermal power plants is under planned repairs.

\section{Conclusions}

As of today, for optimal management of renewable energy sources in the energy system of the Republic of Crimea and the city of Sevastopol, it is necessary to improve forecasting methods for shortterm and operational forecasting. 
For the further development of renewable energy sources on the territory of the Crimean Peninsula, it is necessary to adapt the existing regulation resources, technologies and methods of managing the energy system.

It should be noted that work is underway to create a regulatory framework for regulating the work of renewable energy sources. Thus, the Resolution of the Government of the Russian Federation dated 13.08.2018 No. 937 approved the Rules for the Technological Functioning of Electric Power Systems, which for the first time defined the requirements for RES generation at this level. At the same time, there remains a large number of questions regarding the standardization of technical requirements for commissioned renewable energy equipment. In addition to the issue of standardization of technical requirements for RES equipment, for the reliable operation of power systems with a significant amount of RES, it is necessary to develop systems for forecasting the generation of RES [14].

However, the following important factors should not be forgotten, which inspire optimism when considering renewable energy:

1. The cost of fossil fuels is steadily increasing as its reserves decrease.

2. Reasonable government policy makes the use of RES more profitable.

3. Taking into account the progress, the efficiency of renewable energy is increasing, new technologies are being developed in the generation and storage of electricity.

\section{References}

1. Belokrylova E.A., Kologermanskaya E.M. [Modern political and legal aspects of the development of renewable energy sources in the Russian Federation]. Vestnik Udmurtskogo universiteta, 2017, vol. 27, no. 2, pp. 85-93 (in Russ.).

2. Variable but predictable: Forecasting renewable power generation. Clean energy Wire, 2016, pp. 1-7.

3. Krivtsov V.S., Oleinikov A.M., Yakovlev A.I. Al'ternativnaya energetika [Alternative energy]. Khar'kov, KhAI Publ., 2007, 660 p. (in Russ.).

4. Shirokov A.V., Shimon N.S. [Problems of energy supplyin the Republic of Crimea]. Pozharnaya bezopasnost': problemy i perspektivy, 2017, vol. 1, pp. 47-49 (in Russ.).

5. Usachev A.M. [Analysis of the dynamics of the global industry of solar energy]. Naukovedenie, 2015, vol. 7, no. 4 (in Russ.). Available at: http://naukovedenie.ru/ PDF/10EVN415.pdf
6. Zhukov V.P., Osipov D.A., Ulanov D.A., Ledukhovskii G.V., Barochkin E.V. [Optimal control of the structure and operational modes of integrated energy systems]. Vestnik Ivanovskogo gosudarstvennogo energeticheskogo universiteta, 2016, vol. 2, pp. 33-37 (in Russ.).

7. Perminov E.M. [Energy of the Republic of Crimea state and problems of development]. Energetik, 2014, no. 5, pp. 7-10 (in Russ.).

8. Zhilina N.A. [Calculation of load capacities of electric energy by the probabilistic-statistical method]. Nauchnyi Vestnik Novosibirskogo gosudarstvennogo tekhnicheskogo universiteta, 2014, no. 2, pp. 176-182 (in Russ.).

9. Guryev V.V., Kuvshinov V.V. Optimizatsiya metodov prognozirovaniya vyrabatyvaemoi moshchnosti solnechnykh elektrostantsii $v$ energosisteme Respubliki Krym i goroda Sevastopolya [Optimization of methods for predicting the generated capacity of solar power plants in the power system of the Republic of Crimea and the city of Sevastopol]. Materialy mezhdunarodnoi nauchno-prakticheskoi konferentsii "Ekologicheskaya, promyshlennaya $i$ energeticheskaya bezopasnost' 2018" (Sevastopol', 24-27 sentyabrya 2018 g.) [Proc. international scientific-practical conference "Environmental, Industrial and Energy Security - 2018" (Sevastopol, September 24-27, 2018)]. Sevastopol, 2018, pp. 325-327 (in Russ.).

10. Dzhumaev A.Ya. Analiz vliyaniya temperatury na rabochii rezhim fotoelektricheskoi solnechnoi stantsii [Analysis of the effect of temperature on the operating mode of a photovoltaic solar station]. Materialy XLVI Mezhdunar. nauch.-prakt. konf. "Tekhnicheskie nauki ot teorii k praktike" (Novosibirsk, 27 maya 2015 g.). [Proc. XLVI International scientific-practical conf "Engineering - from theory to practice" (Novosibirsk, May 27, 2015)]. Novosibirsk, 2015, no. 5, pp. 33-40 (in Russ.).

11. Rybkina Ya.A. [The legal nature of the selection of renewable energy projects and the application of antitrust laws to the procedure for selecting renewable energy projects]. Pravovoi energeticheskii forum, 2018, no. 4, pp. 38-45 (in Russ.).

12. Chivenkov A.I., Krakhmalin I.G. [Universal converter as a basis for coordinating the parameters of distributed network sources with renewable energy sources]. Intellektual'naya elektrotekhnika, 2018, no. 1, pp. 112-125 (in Russ.).

13. Vologdin S.V., Guryev V.V., Yakimovich B.A., Kuvshinov V.V. [A mathematical model for optimizing the operation of the power system of the Republic of Crimea and the city of Sevastopol]. Energeticheskie ustanovki i tekhnologii, 2018, vol. 4, no. 4, pp. 50-54 (in Russ.).

14. Orlov A. [Payback of renewable energy projects: not as difficult as it seems]. Energiya: ekonomika, tekhnika, ekologiya, 2018, no. 11, pp. 70-72 (in Russ.). 


\section{Перспективы развития возобновляемых источников энергии на территории Крымского полуострова}

B. В. Гурьев, аспирант, Севастопольский государственный университет; АО «СО ЕЭС «Черноморское РДУ», Севастополь, Россия

B. В. Кувшинов, кандидат технических наук, Севастопольский государственный университет, Севастополь, Россия

Б. А. Якимович, доктор технических наук, профессор, Севастопольский государственный университет, Севастополь, Россия

Крымский полуостров сегодня - флагман развития возобновляемой энергетики, поскольку является не только активно развиваюшимся регионом, но и курортным иентром. Энергетический комплекс Крымского полуострова за последние годы увеличился благодаря строительству новых электрических станций (Балаклавской ТЭС и Таврической ТЭС) суммарной мошностью 940 MВт, а также строительству новых ЛЭП 220 и 330 кB, что обеспечило покрытие дефицита энергоснабжения полуострова. Произведен обзор регионального развития и использования возобновляемых источников энергии. На основании полученных данных проведен анализ проблем и перспектив развития возобновляемой энергетики в регионе.

Развитие возобновляемых источников энергии (ВИЭ) для Крымского полуострова играет важную роль в иелях достижения экологической безопасности и развития экономического потенциала региона. Обосновано приоритетное использования ВИЭ в регионе, а также решение возникаюших проблем при увеличении доли ВИЭ в составе суммарной генерации. Появление избытка электроэнергии в энергосистеме и наличие возможности балансирования вырабатываемой мощчнсти ВИЭ и тепловых электростанций ведет к снижению стоимости электроэнергии. Инвестиционная привлекательность и активный рост населения в регионе обусловливает увеличение генерирующей мощзности и увеличение маневренности энергосистемы при существенном влиянии возобновляемых источников энергии. Эффективность работы ВИЭ в энергосистеме, мировой опыт управления генераџией ВИЭ, фактическое влияние ВИЭ на энергосистему в условиях дефиџита электроэнергии, прогнозные графики работы солнечных электростанций (СЭС) ВЭС, предоставляемые субъектами электроэнергетики в установленном порядке, учитываются при формировании диспетчерского графика.

Существуюший опыт действующих СЭС в энергосистеме Республики Крым и г. Севастополя требует дополнительных исследований, в том числе путем проведения натурных испытаний генерирующего оборудования. Дальнейшие натурные испытания долюнны проводиться в условиях реального электроэнергетического режима работы энергосистемы, для чего требуется внедрение современных информационных технологий, обеспечивающих обмен технологической информаџией и реализаџию соответствующих управляющих воздействий. Ведется работа по созданию нормативной базы регулирования работы ВИЭ.

Ключевые слова: баланс мощности, экология, возобновляемая энергетика, энергия солнца и ветра, натурные испытания.

Получено 11.11.2019

\section{For Citation}

Guryev V.V., Kuvshinov V.V., Yakimovich B.A. Prospects for the Development of Renewable Energy in the Crimean Peninsula = Perspektivy razvitiya vozobnovlyaemykh istochnikov energii na territorii Krymskogo poluostrova. Vestnik IzhGTU imeni M.T. Kalashnikova, 2021, vol. 24, no. 4, pp. 109-115. DOI: 10.22213/2413-1172-2021-4-109-115. DOI: 10.22213 / 2413-1172-2019-4-116-123 (in Russ.). 